\title{
Acute alcohol intoxication: uncommon complication associated to celiac plexus neurolysis during open surgical procedure in patient with refractory cancer pain. Case report
}

\author{
Intoxicação alcóolica aguda: complicação rara associada a neurólise do plexo celíaco durante \\ procedimento cirúrgico a céu aberto em paciente com dor oncológica refratária. Relato de caso
}

Giselle Lima Afonso ${ }^{1}$, Mirlane Guimarães de Melo Cardoso ${ }^{1,2,3}$, Ivandete Pereira Coelho ${ }^{1,3}$, Bárbara Guimarães de Melo Cardoso ${ }^{4}$

DOI 10.5935/1806-0013.20160033

\section{ABSTRACT}

BACKGROUND AND OBJECTIVES: Celiac plexus neurolysis is a pain management option for patients with abdominal cancer refractory to other approaches. It is followed by adverse reactions which may be diagnosed and treated, provided patients are monitored and followed up immediately after the procedure. This study aimed at reporting the case of a patient submitted to celiac plexus neurolysis who evolved with acute alcohol intoxication diagnosed in the post-anesthetic care unit.

CASE REPORT: Female patient, 43 years old, with pancreatic head cancer, submitted to intraoperative celiac plexus neurolysis with $40 \mathrm{~mL}$ of $98 \%$ alcohol. Patient evolved in the postanesthetic care unit with hypotension, hypoxemia and mental confusion, which were reverted with intravenous hydration and elevation of lower limbs.

CONCLUSION: Celiac plexus alcoholization permanently blocks visceral pain of pancreatic cancer patients, however it is not free of adverse reactions, which may evolve to severe complications if not promptly diagnosed, making mandatory the follow up of patients in the post-anesthetic care unit.

Keywords: Acute alcohol intoxication, Cancer pain, Celiac plexus neurolysis

\section{RESUMO}

JUSTIFICATIVA E OBJETIVOS: A neurólise do plexo celíaco é uma opção de tratamento da dor para pacientes com câncer abdominal refratário a outras abordagens. É acompanhada de reaçóes ad-

1. Hospital Universitário Getúlio Vargas, Instituto de Anestesiologia do Amazonas, Manaus, AM, Brasil.

2. Universidade Federal do Amazonas, Instituto de Ciências Biológicas, Departamento de Ciências Fisiológicas, Manaus, AM, Brasil.

3. Sociedade Brasileira de Anestesiologia, Rio de Janeiro, RJ, Brasil.

4. Universidade Federal do Amazonas, Graduanda de Medicina, Manaus, AM, Brasil.

Submitted in August 01, 2015.

Accepted for publication in March 23, 2016.

Conflict of interests: none - Sponsoring sources: none.

Correspondence to:

Av. General Rodrigo Octávio, 6200 - Coroado I

69077-000 Manaus, AM, Brasil.

E-mail: giselle.afonso88@gmail.com

(C) Sociedade Brasileira para o Estudo da Dor versas que são diagnosticadas e tratadas desde que o paciente receba monitorização e acompanhamento imediato após o procedimento. O objetivo deste estudo foi relatar o caso de uma paciente submetida a neurólise de plexo celíaco, evoluindo com sintomas de intoxicação alcoólica aguda diagnosticada na sala de recuperação pós-anestésica. RELATO DO CASO: Paciente do gênero feminino, 43 anos, com neoplasia de cabeça de pâncreas submetida a neurólise de plexo celíaco intraoperatório com $40 \mathrm{~mL}$ de álcool a $98 \%$, evolui na sala de recuperação pós-anestésica com hipotensão, hipoxemia e confusão mental, sintomas esses revertidos com hidratação por via venosa e elevação de membros inferiores.

CONCLUSÁO: A alcoolização do plexo celíaco bloqueia definitivamente a dor visceral de pacientes com neoplasia de pâncreas, porém não está isenta de reaçóes adversas, as quais podem evoluir para complicaçóes graves caso não sejam prontamente diagnosticadas, tornando-se imprescindível o acompanhamento do paciente na sala de recuperação pós-anestésica.

Descritores: Dor oncológica, Intoxicação alcoólica aguda, Neurólise do plexo celíaco.

\section{INTRODUCTION}

Celiac plexus neurolysis (CPN) is the permanent ablation with alcohol or phenol, aiming at interrupting the transmission of sensory pathways formed by afferent fibers of thoracic and lumbar nerves (sympathetic component, from $T_{5}$ to $T_{12}$ ), vagus nerve (parasympathetic component) and phrenic nerves (motor component). Celiac plexus-transmitted pain comes from upper abdomen. CPN may be performed by posterior or anterior access, by percutaneous route or under direct view during laparotomy, as in this case. Prototype of cancer pain management, $\mathrm{CPN}$ is indicated for abdominal visceral pain refractory to systemic analgesic therapy ${ }^{1}$. With progressively more sophisticated techniques, it promotes further analgesic efficacy and lower incidence of transient catheter complications, such as low back or abdominal pain, diarrhea and posture hypotension. Neuritis, pneumothorax, acute alcohol intoxication, epidural and spinal injection, paraplegia, vascular injection, vessels and visceral puncture, hematoma and peritonitis are rare complications and their incidence is related to different techniques and accesses, thus being uncommon the incidence of such complications in open procedures, since neurolysis is performed under direct view of structures. So, one should be alert to the presence of adverse 
reactions and hemodynamic and neurologic complications ${ }^{2}$. This study aimed at reporting the case of a female patient submitted to celiac plexus neurolysis, who has evolved with acute alcohol intoxication symptoms diagnosed in the postanesthetic care unit (PACU).

\section{CASE REPORT}

Female patient, 43 years old, with pancreatic head cancer for 2 months, admitted to the first aid unit of the Fundação Centro de Controle de Oncologia do Estado do Amazonas, complaining of severe abdominal jumping pain - visual analog scale (VAS) 9, located on right hypochondrium, constant, however with moments of crisis, without irradiation, followed by vagal symptoms, such as bright scotomia and fainting, progressive and refractory to pharmacological therapy with transdermal fentanyl. Medical history: no comorbidities and allergies. Laboratory tests and electrocardiogram were within normal parameters. Surgical procedure to remove neoplastic mass was scheduled for the day following admission (Whipple surgery). Patient was submitted to epidural anesthesia with puncture at $\mathrm{L}_{1}-\mathrm{L}_{2}$, followed by administration of $0.25 \%$ bupivacaine $(20 \mathrm{~mL})$ and morphine $(2 \mathrm{mg})$. General anesthesia was induced with fentanyl $(150 \mu \mathrm{g})$, propofol $(150 \mathrm{mg})$ and rocuronium $(35 \mathrm{mg})$, tracheal intubation and anesthetic maintenance with $2 \%$ sevoflurane. One hour after surgical procedure, the surgical team concluded that it was not possible to perform proposed procedure, since it was a bulky mass without cleavage plane, adhered to aorta and vena cava. We decided for palliative approach and future follow-up with chemotherapy, aiming at regressing tumor volume and further surgical evaluation. So, CPN was performed by the surgical team with $98 \%$ alcohol $(40 \mathrm{~mL})$ under direct view, followed by sudden hypotension $(65 \times 35 \mathrm{mmHg})$, responsive to intravenous administration of $1000 \mathrm{~mL} 0.9 \%$ saline solution and ethylephrine $(2 \mathrm{mg})$. Surgery went on without other intercurrences being patient transferred to the PACU where she evolved with neurological symptoms compatible with inebriation.

Patient then presented lower conscious level, mental confusion, slurred speech, motor uncoordination when obeying to simple commands, such as touching her shoulder, $\mathrm{SpO}_{2} 72 \%$, and hypotension when changing position $(68 \times 38 \mathrm{mmHg})$. Blood glycemia was $128 \mathrm{mg} / \mathrm{dL}$. Lower limbs were elevated to optimize venous return, and patient was hydrated with $500 \mathrm{~mL}$ of rapid phase lactated Ringer solution. Patient improved pressure $(129 \times 76 \mathrm{mmHg})$, saturation $\left(\mathrm{SpO}_{2} 96 \%\right.$ in room air) and neurological symptoms, with Glasgow comma score of 15, being discharged from PACU after two hours of observation, without pain complaints $(V A S=2)$. Twenty-four hours after surgery, patient had evolved without intercurrences in the ward, with significant pain improvement $(\mathrm{VAS}=1)$.

\section{DISCUSSION}

Celiac plexus block is considered the most effective neurolytic block and the first line therapy for pancreatic cancer pain, controlling $89 \%$ of cases in the first two weeks, and maintaining adequate analgesia in 70 to $90 \%$ of patients in the first three months $s^{3,4}$. However, the risk of paraplegia by possible medullary infarction, although rare, limits its early indication and explains its more common use in advanced cancer stages $^{5,6}$, as in our case report.

Of major importance to perform CPN is knowing the anatomy of neighbor structures which shall be object of potential trauma by needles and drugs, although the risk of inadvertent injection is lower in the technique under direct view, such as in our case report. Celiac plexus is made up of right and left celiac ganglia, anterolateral to the aorta, below the celiac artery, at the level of the first lumbar vertebra. It is located in the epigastrium, posterior to stomach and pancreas and anterior to diaphragmatic pillars where it involves the celiac trunk, upper mesenteric arteries and the aorta ${ }^{6}$. Severe abdominal pain is present in up to $33 \%$ of patients with pancreatic cancer at diagnosis time, in $50 \%$ of those under treatment, in $90 \%$ with advanced disease and in $84 \%$ of patients submitted to palliative surgery ${ }^{7}$. Infiltration and invasion of peripancreatic nerves are primary pain mechanisms, added to increased pressure and intraductal obstruction, capsule stretching, and infiltration to celiac and retroperitoneal lymph nodes. CPN may be performed in several ways: percutaneous with the help of computerized tomography (CT) or fluoroscopy, ultrasound-guided (USG), by endoscopic route or during the intraoperative period. In all techniques it is recommended that patients are monitored for two to four hours after procedure to detect possible complications ${ }^{7}$. In the intraoperative approach, as decided by patient's surgical team, CPN is performed with injection of $10 \mathrm{~mL}$ of $98 \%$ alcohol. Mean administered volume, regardless of the technique, is approximately $15 \mathrm{~mL}^{8}$. Note that the volume administered to patient $(40 \mathrm{~mL})$ was higher than that found in the literature, which may be related to intraoperative hypertension and complications detected at PACU, especially neurological ones associated to alcohol intoxication, similar to inebriation, tachycardia, facial flushing, cold sweating, agitation and confusion, dysarthria and motor changes. Such effects are directly proportional to the alcohol mass injected and consequently absorbed, and are clinically related to alcohol intoxication. Sato et al. ${ }^{6}$ have shown in 11 patients submitted to $\mathrm{CPN}$ that $10 \mathrm{~mL}$ of absolute alcohol were enough to trigger a classic presentation of alcohol intoxication, as from the evaluation of alcohol concentrations of radial artery and jugular vein in moments $0,5,10,15$, 30, 60, 120, 240 and 480 minutes after blockade. Maximum level was reached 15 minutes after injection, both in arterial and venous blood. Similarly, patient had decreased pressure levels at intraneural injection, and has again manifested such symptom in the PACU, with good response to fluid infusion, now associated to acute alcohol intoxication/inebriation, which have acted as marker of effective systemic absorption ${ }^{8}$. One should stress in this case the importance of following such patients in the PACU, not only as routine related to anesthetic technique, but also to evaluate and be familiar with 
invasive techniques to control pain and possible postoperative complications. CPN, as well as neurolysis of other sympathetic plexus and ganglia, is useful and effective to abolish abdominal and pelvic pain in cancer patients. In fact, it was observed that patient had significant pain improvement, since $24 \mathrm{~h}$ after procedure pain intensity has improved from VAS 9 to 1 . Complications of such technique are rare, and adverse effects are, in their majority, reversible and responsive to treatment. Benefits of this method are related not only to pain relief, but also to decreased use of analgesics (and their respective adverse effects), in addition to improving quality of life not only of advanced disease patients ${ }^{8-10}$. Neurolysis, by interrupting nociceptive pathway, may indirectly change response to stress and disease-related behavior. It is also worth stressing that pain and stress stimulate metastatic propagation and that an effective pain control or change in stress response may have a protective effect on the immune system. So, cancer patients' pain control is not only ethic, but may also improve their life expectancy $^{8-10}$.

\section{REFERENCES}

1. Yamamuro M, Kusaka K, Kato, M, Takahashi M. Celiac plexus block in cancer pain management. Tohoku J Exp Med. 2000;192(1):1-18

2. Davies DD. Incidence of major complications of neurolytic coeliac plexus block. J R Soc Med. 1993;86(5):264-6.

3. Penman ID, Gilbert D. Basic technique for celiac plexus block/neurolysis. Gastroin Endosc. 2009;69(2 Suppl):S163-5.

4. Sakorafas GH, Tsiotou AG, Sarr MG. Intraoperative celiac plexus block in the surgical palliation for unresectable pancreatic cancer. Eur J Surg Oncol. 1999;25(4):427-31.

5. StaatsPS, HekmatH, Sauter P, Lillemoe, K. The effects of alcohol celiac plexus block, pain and mood on longevity in patients with unresectable pancreatic cancer: a doubleblind, randomized, placebo-controlled study. Pain Med. 2001;2(1):28-34.

6. Sato S, Okubo N, Tajima K, Takahashi H, Fukuda T. Plasma alcohol concentrations after celiac plexus block in gastric and pancreatic cancer. Reg Anesth. 1993;18(6):366-8.

7. Erdek MA, Halpert DE, González Fernández M, Cohen SP. Assessment of celiac plexus block and neurolysis outcomes and technique in the management of refractory visceral cancer pain. Pain Med. 2010;11(1):92-100.

8. ZhongW, Yu Z, Zeng JX, Lin Y, Yu T, Min XH, et al. Celiac plexus block for treatment of pain associated with pancreas cancer: a meta-analysis. Pain Pract. 2014;14(1):43-51.

9. Arai YC, Morimoto A, Sakurai H, Ohmichi Y, Aono S, Nishihara M, et al. The effect of celiac plexus block on heart rate variability. J Anesth. 2013;27(1):62-5.

10. Wyse JM, Carone M, Paquin SC, Usatii M, Sahai AV. Randomized, double-blind, controlled trial for early endoscopic ultrasound-guided celiac plexus neurolisys to prevent pain progression in patients with newly diagnosed, painful, inoperable pancreatic cancer. J ClinOncol. 2011;29(26):3541-6. 